\title{
The impact of institutional trading on stock prices
}

\section{Citation}

Lakonishok, Josef, Andrei Shleifer, and Robert W. Vishny. 1992. “The Impact of Institutional Trading on Stock Prices." Journal of Financial Economics 32 (1) (August): 23-43. doi:10.1016/0304-405x(92)90023-q.

\section{Published Version}

doi:10.1016/0304-405X(92)90023-Q

\section{Permanent link}

http://nrs.harvard.edu/urn-3:HUL.InstRepos:27692662

\section{Terms of Use}

This article was downloaded from Harvard University's DASH repository, and is made available under the terms and conditions applicable to Other Posted Material, as set forth at http:// nrs.harvard.edu/urn-3:HUL.InstRepos:dash.current.terms-of-use\#LAA

\section{Share Your Story}

The Harvard community has made this article openly available.

Please share how this access benefits you. Submit a story.

Accessibility 
NBER WORKING PAPERS SERIES

DO INSTITUTIONAL INVESTORS DESTABILIZE STOCK PRICES? EVIDENCE ON HERDING AND FEEDBACK TRADING

Josef Lakonishok

Andrei Shleifer

Robert w. Vishny

Working Paper No. 3846

NATIONAL BUREAU OF ECONOMIC RESEARCH

1050 Massachusetts Avenue

Cambridge, MA 02138

September 1991

We are grateful to Louis Chan, Jay Ritter, Jeremy Stein, and Richard Thaler for helpful comments; and especially to Gil Beebower and Vasant Kamath for guidance with the data. Financial support from LOR-Nikko and Dimensional Fund Advisors is gratefully acknowledged. This paper is part of NBER's research program in Financial Markets and Monetary Economics. Any opinions expressed are those of the authors and not those of the National Bureau of Economic Research. 
NBER Working Paper $\$ 3846$

Sept ember 1991

DO INSTITUTIONAL INVESTORS DESTABILIZE STOCK PRICES?

EVIDENCE ON HERDING AND EEEDBACK TRADING

\begin{abstract}
This paper uses a new data set of quarterly portfolio holdings of 769 all-equity pension funds between 1985 and 1989 to evaluate the potential effect of their trading on stock prices. We address two aspects of trading by money managers: herding, which refers to buying (selling) the same stocks as other managers buy (sell) at the same time; and positive-feedback trading, which refers to buying winners and selling losers. These two aspects of trading are commonly a part of the argument that institutions destabilize stock prices. At the level of individual stocks at quarterly frequencies, we find no evidence of substantial herding or positive-feedback trading by pension fund managers, except in small stocks. Also, there is no strong cross-sectional correlation between changes in pension funds' holdings of a stock and its abnormal return.

Josef Lakonishok Department of Finance University of Illinois at Urbana-Champaign Chicago, IL 61820

Robert W. Vishny Graduate School of Business University of Chicago 1101 East 58th street Chicago, IL 60637 and NBER

Andrei Shleifer

Department of Economics Harvard University Littauer Center 315 Cambridge, MA 02138 and NBER
\end{abstract}


DO INSTITUTIONAL INVESTORS DESTABLIZE STOCK PRICES?

\section{Introduction}

Contrary to the predictions of the standard asset pricing model, the vast majority of investors do not just buy and hold the market portfolio of stocks. Instead, most investors follow strategies of actively picking and trading stocks. When investors trade actively, their buying and selling decisions may move stock prices. Understanding the behavior of stock prices then requires understanding the investment strategies of active investors.

Institutional investors hold about 50 percent of the equities in the United States. In 1989, their trading and that of member firms accounted for 70 percent of the trading volume on the New York Stock Exchange (Schwartz and Shapiro 1990). It may be the case, then, that institutional investors' trades influence stock prices. In this paper, we use data on the changes in a large number of institutional investors' portfolios to find out whether they herd; whether they follow positive-feedback strategies; and whether their trading is associated with stock price movements. Answers to these questions allow some tentative conclusions about the likely impact of institutional activity on stock prices.

There are two extreme views of the impact of institutional investors on stock prices. According to the first view, institutions destabilize asset prices, which usually means that they move prices away from fundamental values, thereby increasing longrun price volatility. This view rests to a large extent on two premises. The first premise is that swings in institutional demand have a larger effect on stock prices than swings in individual demand. In part, any given institution has much larger holdings than most individuals do, and so its trades are much larger. More importantly, this problem may be aggravated by herding, i.e., correlated trading across institutional-investors. When large investors attempt to buy or sell a given stock at 
the same time, their effect on its price can be large indeed. A pension fund manager has described this problem succinctly: "Institutions are herding animals. We watch the same indicators and listen to the same prognostications. Like lemmings, we tend to move in the same direction at the same time. And that, naturally, exacerbates price movements" (WSJ, October 17, 1989).

There are several reasons why institutions might herd more than individuals. First, institutions might try to infer information about the quality of investments from each others' trades and herd as a result (Shiller and Pound 1989, Banerjee 1991). Since institutions know more about each others' trades than do individuals, they will herd more. Second, the objective difficulties in evaluating money managers' performance and separating "luck" from "skill" create agency problems between institutional money managers and fund sponsórs. Typically, money managers are evaluated against each other. To avoid falling behind a peer group by following a unique investment strategy, they have an incentive to hold the same stocks as others do (Scharfstein and Stein 1990). Third, institutions might all react to the same exogenous signals, such as changes in dividends or analysts' recommendations, and herd as a result. Because the signals reaching institutions are typically more correlated than the signals that reach individuals, institutions might herd more. When many large institutional money managers end up on the same side of the market, we expect the stock price to move as long as the excess demand curve for this stock slopes downward.

Herding by itself, however, does not necessarily mean that institutional investors are destabilizing stock prices. As we mentioned above, they might herd if they all react to the same fundamental information in a timely manner. If they do, they are making the market more efficient by speeding up the adjustment of prices to new 
fundamentals. Or they might herd if they all counter the same irrational moves in individual investor sentiment. In this case as well, herding is stabilizing. In such cases, observing herding does not suffice to conclude that institutional investors destabilize prices.

This leads to the second premise of the argument that institutions destabilize stock prices: their strategies tend not to be based on fundamentals. A possible reason for this premise as well is agency problems in money management. Fundamental strategies, such as the Graham-Dodd contrarian investment strategies of buying "cheap" high-dividend yield or high-book-to-market stocks, often take a long time to pay off, and may actually do very badly in the short run. Money managers, however, can be dismissed after only a few quarters of bad performance, and, therefore, contrarian strategies put managers at significant risk. As a consequence, money managers might follow short-term strategies based not on fundamentals, but on technical analysis and other types of feedback trading.

One particularly common example of a potentially destabilizing short-term strategy is trend chasing, or positive-feedback trading (De Long et al 1990, Cutler, Poterba and Summers 1990)-the strategy of buying winners and selling losers. Such trading might simply be driven by a belief that trends are likely to continue, a popular concept in the behavioral literature (Andreassen and Kraus 1988). From the money manager's perspective, the strategy of adding winners to the portfolio and eliminating losers has the added advantage of removing "embarrassments" from the portfolio for the sake of the sponsors, i.e., "window dressing."

Positive-feedback trading would be destabilizing if it leads institutions to jump on the bandwagon and buy overpriced stocks and sell underpriced stocks, thereby contributing to a further divergence of prices away from fundamentals. Positive- 
feedback trading is not necessarily a destabilizing strategy: for example, such trading will bring prices closer to fundamentals if stocks underreact to news. Nonetheless, positive-feedback trading, like herding, is associated with the popular belief that institutional investors destabilize stock prices. The prevalence of herding and of positive-feedback trading by institutional investors are, therefore, the focus of our empirical analysis.

An opposing view of institutional investors argues that they are rational and coolheaded investors who counter changes in the sentiment of individual investors. Unlike individual investors, institutions are exposed to a variety of news reports and analyses, as well as to the guidance of professional money managers. This puts them in a better position to evaluate the fundamentals. According to this view, institutions may or may not herd. They would herd if they all received the same information and interpreted it similarly, or if they countered the same swings in individual investor sentiment. But they would not herd if they received uncorrelated information or interpreted the same information in different ways.

More importantly, this view predicts that rational institutions are likely to pursue negative-feedback strategies of buying stocks that have fallen too far and selling stocks that have risen too far. Although it is possible that trend chasing is a rational strategy if individuals underreact to news, the most commonly argued notion of market irrationality is overreaction (De Bondt and Thaler 1985), which would make negativefeedback strategies rational. The stabilizing view then predicts that institutions sell stocks that have risen and buy stocks that have fallen.

There is also a third, and more neutral, view of institutional investors. On that view, institutions are neither the smart negative-feedback investors, nor are they the destabilizers who herd and chase trends. Instead, institutions are heterogeneous: they 
use a broad variety of different portfolio strategies, which by and large offset each other. Such trading does not destabilize asset prices because there are enough negative-feedback traders to offset the positive-feedback traders. In addition, the diversity of the trading strategies is great enough that the aggregate excess demand by institutions is close to zero, so that no herding emerges in equilibrium. Pursuit of these various strategies is therefore fairly benign, for although it might generate a substantial trading volurne, institutions are not destabilizing stock prices.

In this paper we empirically examine the trading patterns of institutional investors, with a particular emphasis on the issues of herding and positive-feedback trading that have attracted so much attention. We evaluate a sample of 769 all-equity pension funds, managed by 341 different institutional money managers. The data were provided by a pension fund performance evaluation service, SEI. This sample is particularly appropriate for addressing the questions of herding and positive-feedback trading. These money managers directly compete with each other, both because they pursue the same customers, and because they are evaluated by the same service. This selection criterion creates scope for finding more herding and positive-feedback trading in this sample of institutions than in a random sample of institutions.

Our data consist of end-of-quarter portfolio holdings for each of the 341 money managers between 1985:1 and 1989:4. These data enable us to estimate how much each manager bought and sold in each stock in each quarter. We can then assess how much correlation there is across money managers in buying and selling a given stock (or industry grouping) to test for herding. We can also examine the relationship between the past performance of a stock and money managers' demands for that stock to test for positive-feedback trading. Finally, we can examine the relationship between the excess demand by institutions and contemporaneous stock price changes 
directly. Answers to these questions shed light on the potential destabilizing effect of institutional investors.

In brief, our results suggest that neither the stabilizing nor the destabilizing image of institutional investors is accurate. There is virtually no evidence that institutions herd in their trades in large stocks, which is where over $95 \%$ of their trading is concentrated. There is some evidence of herding in smaller stocks, but even there the magnitude of herding is far from dramatic. As far as trading strategies go, on average, institutions appear to follow neither positive nor negative-feedback strategies. There is some evidence of positive-feedback trading in smaller stocks, but not in large stocks which are the institutions' preferred habitat. Finally, the correlation between excess demand by institutions for a stock in a given quarter, and its price change in that quarter is extremely weak. This provides some evidence against the view that large swings in institutional excess demand drive price movements of individual shares. The overall picture of institutions that emerges from this paper is one of investors pursuing a broad diversity of trading styles that, to a large extent, offset each other.

These results are most closely related to research done some twenty years ago. In a remarkable early paper, Kraus and Stoll (1972) addressed the question of "parallel trading," which is the same as herding, by institutions, using the data from the SEC study of institutional investors on monthly changes in holdings. Like ourselves, they found little evidence of herding, and weak evidence of a contemporaneous relationship between price changes and excess demand by institutions. Also of great interest and relevance is the study of mutual funds by Friend, Blume, and Crockett (1970). One of their findings related to the current paper is that mutual funds tend to buy stocks which in the previous quarter were 
bought by successful funds, whom they are probably imitating. Such behavior would lead to herding, as well as to positive-feedback trading.

The remainder of this paper is organized as follows. The next section describes our data in more detail. Section 3 examines the issue of herding. Section 4 deals with feedback trading strategies. Section 5 presents direct evidence on the correlation between institutional demand and prices and Section 6 concludes the paper.

\section{Data}

The analysis is based on a sample of 769 tax-exempt equity funds provided by SEI, a company that specializes in portfolio performance evaluation. According to the SEI definition, equity funds hold at least 90 percent of their assets in equities. For each fund, at the end of each quarter from 1985 to 1989 , the dataset contains the number of shares held of each stock. Sponsors of most of the funds are corporate pension plans, but there are aiso a few endowments, as well as state and municipal pension funds.

The total amount under management in these 769 funds at the end of 1989 is $\$ 124$ billion, or about 18 percent of the total actively managed holdings of pension funds. The average equity holdings of a fund are $\$ 161$ million. Equity purchases and sales are estimated based on changes in holdings from end-of-quarter to end-ofquarter of all NYSE, AMEX, and OTC stocks that funds held. The prices used to estimate dollar values are averages of beginning and end-of-quarter stock prices. All holdings and prices are adjusted for stock splits and stock dividends. The data do not allow us to measure intraquarter round-trip transactions. Such transactions are infrequent and should have a minor impact on the results, particularly since we are interested only in price destabilization at frequencies below one quarter.

Typically, a money manager has more than one fund under management. In our 
case, the 769 funds are managed by 341 different money managers, with the number of funds under one management ranging from 1 to 17 . In general, different funds managed by the same manager have similar, if not identical, holdings. Therefore, the appropriate unit of analysis for this paper is a money manager rather than a fund. All the holdings of different funds with the same money manager are therefore aggregated. Money managers in our sample might manage additional funds that are not in our sample, which will happen, for example, if these funds are not evaluated by SEI. The average portfolio of a money manager at the end of 1989 is $\$ 363$ million. Twenty-three money managers had more than one billion dollars under management and the largest money manager in the sample had twelve billion dollars.

An important part of this paper will be the distinction between the trading strategies of money managers in large and small stocks. It is, therefore, important to note that the vast majority of holdings and trading of these investors are in large stocks. Table 1 presents information on buying and selling activity by size (market capitalization) quintiles. The cut-off points for size quintiles were determined from the universe of NYSE and AMEX stocks and updated quarterly. The table presents the number of portfolio changes and the dollar value traded in each size quintile.

Taking each quarterly change in a stock as a separate observation, we have a total of 26,292 cases where holdings were changed by at least one money manager in our universe. Only 338 of these changes, or 1.3 percent, are in the smallest quintile stocks. In contrast, 35.7 percent of the changes are in the largest quintile stocks, and an additional 34 percent are in the next to the largest quintile. In terms of dollar values, the results are even more dramatic. While only .07 percent of holding changes by value are in the smallest quintile of stocks, fully 84 percent are in the largest quintile of stocks, and another 12.7 percent in the second largest. Roughly 
speaking, 97 percent of the dollar value traded by money managers is in the largest

40 percent of the stocks by market capitalization. The bottom line is that institutional investors trade large stocks. This observation is important to keep in mind in interpreting our findings on herding and positive-feedback trading.

\section{Herding}

\section{Measurement of Herding}

In this section we explore whether money managers tend to end up on the same side of the market in a given stock in a given quarter. In other words, for a specific stock in a given quarter, are a disproportionate number of money managers buying (selling) this stock? To illustrate our measure of herding, assume that, in a given quarter, when aggregated across stocks and money managers, half of the changes in holdings were increases and half were decreases. Consider first the case where, in that quarter, for most individual stocks as well we observe that half the money managers increased their holdings and half cut their holdings. In this case, we would conclude that there was no herding at the level of individual stocks. Suppose alternatively that, for many stocks, 70 percent of the money managers increased their holdings while only 30 percent decreased holdings. For other stocks, in contrast, 70 percent of the money managers decreased their holdings and 30 percent increased them. In this case, for most stocks, money managers ended up on the same side of the market and we would conclude that there is herding at the level of individual stocks.

Generally, our measure of herding for a given stock in a given quarter $H$, is defined as:

(1) $\mathrm{H}=|\mathrm{B} /(\mathrm{B}+\mathrm{S}) \cdot \mathrm{p}| \cdot \mathrm{AF}$ 
where $B$ is the number of money managers who increase their holdings in the stock in the quarter (net buyers), $\mathrm{S}$ is the number of money managers who decrease their holdings (net sellers), $\mathrm{p}$ is the expected proportion of money managers buying in that quarter relative to the number active, and $\mathrm{AF}$ is the adjustment factor explained below. The herding measures are computed for each "stock-quarter" and then averaged across different subgroups.

In a given quarter, we should not necessarily expect the same number of purchasers and sellers of a stock. In fact, in our sample, 51.5 percent of the quarterly changes in holdings are purchases, consistent with money managers being net buyers during this period. This ratio varies from quarter to quarter. In computing our herding measure $\mathrm{H}$, we therefore have a different $\mathrm{p}$ for every quarter. Each quarterly $\mathrm{p}$ is the number of money managers buying relative to the number active, aggregated across all stocks that the money managers traded in that quarter.

The adjustment factor AF in equation (1) accounts for the fact that under the null hypothesis of no herding, i.e., when the probability of any money manager being a net buyer of any stock is $p$, the absolute value of $B /(B+S)-p$ is greater than zero. $A F$ is, therefore, the expected value of $|B /(B+S)-p|$ under the null hypothesis of no herding. Since B follows a binomial distribution with probability p of "success," AF is easily calculated given $\mathrm{p}$ and the number of money managers active in that stock in that quarter. $\mathrm{AF}$ for a stock declines as the number of money managers active in that stock rises.

\section{Empirical results on herding}

Table 2 presents our main results on herding. Because our samples are so large, all results are statistically significant and we do not report standard errors. The first column reports the mean and median herding measures for the whole sample. The 
mean herding measure, .027 , is one of the key numbers in this paper. If $p$, the average fraction of changes that are increases, was .5 , this number would say that in an average stock, 52.7 percent of the money managers were changing their holdings in one direction, and 47.3 percent in the opposite direction. The median herding measure is even smaller, only .001 , which suggests that there is virtually no herding in a typical stock.

Should we be surprised by how low this number is? As a matter of fact, we were. However, there might be an argument that we should not have been. In the market as a whole, aggregating across all traders, there can be no herding, since for every share bought there is a share sold. So, if we think that our sample of money managers is a random sample of traders, we would not expect to find any herding. Herding can only be detected within subsets of investors. We are analyzing one such subset, pension fund managers, and herding within this subset can exist. Some might argue that we should look within a finer subset of money managers who share a similar investment style in order to detect herding. We are not persuaded by this argument.

First, all of the money in our sample is managed by stock-picking pension fund managers evaluated by the same service. We do not have individuals or even most types of institutional investors. It is hard to believe that we have a random sample of U.S. equity investors, given how homogeneous our sample is by construction. In fact, we have argued earlier that restricting our sample to all-equity pension fund managers evaluated by the same service significantly increases the chances of detecting herd behavior.

Second, suppose that there are some large subgroups of institutions, with each subgroup practicing a distinct investment philosophy, and suppose that there is a great 
deal of herding among members of each subgroup. This would raise two possibilities. First, the strategies of different subgroups are uncorrelated and, hence, they do not counter each others' demand shifts. For example, growth money managers destabilize growth stocks and value money managers destabilize low P/E stocks. But, in this case, our measure of herding calculated, even on a random sample of institutions, would detect a lot of herding, since the herding subgroup of institutions would cause the whole set of institutions to be on one side of the market, with individuals taking the other side. Our results reject this possibility, since we do not find much herding looking at all stocks.

The second possibility is that while within subgroups money managers herd, the subgroups trade with each other so as to systematically counter each other's effects on prices. For example, if growth money managers buy a stock, value money managers sell it to them. But in this case, there is no destabilization since money managers just trade with each other. This possibility is consistent with our evidence of very little herding by institutional investors.

For many stocks in our sample the number of managers who changed their holdings in that stock is quite small. In Table 2 we also provide herding results for stocks in which a substantial number of money managers were active (at least 10 and at least 20). This restriction eliminates many of the smaller stocks. The results are similar to our earlier findings of fairly little herding.

There is another intuitive way to look at herding. One can ask: what fraction of purchasing behavior of an individual money manager can be explained by what other money managers are doing? For that, we run a regression across "stock-quarters," in which the dependent variable gets the value of one if a randomly chosen money manager who traded in that stock-quarter is a net buyer and zero if he was a net 
seller. The independent variable is the fraction of money managers active in that stock in that quarter who bought it (excluding the randomly chosen money manager whose behavior we are trying to explain). The slope coefficient in this regression is $.05(\mathrm{t}=13.8)$, but more interestingly, the $\mathrm{R}$-squared is only .7 percent; indicating that, in a cross-section, less than 1 percent of an individual money manager's behavior in a stock can be explained by the aggregate behavior of other money managers in that stock. In sum, the money managers in our sample do not seem to herd very much; they most likely represent a variety of trading styles that result, on average, in uncorrelated trading decisions.

\section{Further Results}

We have established, so far, that, on average, there does not seem to be much herding in individual stocks in our sample. This does not preclude the possibility of more extensive herding in some particular types of stocks, such as stocks of particular size or performance record. Institutions might also be more prone to herd in allocating funds across industry groups compared to individual stocks. Finally, herding may be more prevalent among subgroups of managers than in the aggregate. These possibilities are explored below.

Panel A of Table 3 shows herding by stock size. The stocks in which the money managers were active in a given quarter were assigned into size quintiles. The cut-off points for the size quintiles were determined from the universe of NYSE and AMEX stocks and updated quarterly. Herding was then examined within each of the size groups. The results reveal more herding by institutional investors in small stocks than in large stocks; the observed relationship is monotonic in size. For the smallest quintile stocks, our herding measure is 6.1 percent, while for the largest stocks it is only 1.6 percent. 
The result of greater herding in small stocks has several possible explanations. It might simply reflect unintentional herding, in which all institutions just respond similarly to particular news. For example, they may all want to sell small obscure stocks that have lost value in order to "window dress" their portfolios to avoid embarrassment. Dumping losers may be less of an issue with larger stocks, which are held by many institutions. Conversely, money managers might all want to buy a wellperforming small stock because higher market capitalization increases the stock's liquidity and coverage by analysts.

Intentional herding should also be more prevalent in small stocks. There is less public information about these stocks, and, therefore, managers are much more likely to pay attention to each others' behavior and make decisions based on the trades of others in these stocks. This view of herding is consistent with Banerjee's (1991) idea that herding might result from rational inference under very limited information. The result of greater herding in small stocks is also consistent with Scharfstein and Stein's (1990) agency interpretation of intentional herding. Fund managers may well sell a small stock that other managers also sell in order to avoid embarrassment, but holding onto IBM when others sell it is probably fine. Consistent with this story, Lakonishok et al (1991) find more "window dressing" in small stocks.

We also examined herding, conditional on past performance of the stocks. At the beginning of every quarter, we divided the universe of NYSE and AMEX stocks into past-quarter performance quintiles. Stocks in which the money managers traded were then assigned into these quintiles, and herding measures computed for each group. The results are in Panel B of Table 3. Herding does not seem to depend on past stock performance. At most, there is some weak indication of slightly more herding in better performing stocks. 
One might argue that herding should be more pronounced within certain industry groups of stocks, such as technology stocks, whose cash flows are much more uncertain. For example, one might expect to observe more herding in Apple Computers than in a less glamorous stock like General Motors. To test this hypothesis, we have divided the stocks in our sample into eleven broad industry groupings, provided to us by SEI, and computed our herding measure for each group. Again, we did not find much herding in any group. The measure of herding within various industry groups ranged between .029 and .015 . There is no industry with an unusually large amount of herding.

Another hypothesis is that money managers herd in their portfolio allocations across industries rather than across individual stocks. For example, when money managers are "excited" about computer stocks, one of them might buy IBM, another might buy Apple Computers, and the third might buy COMPAQ, leading to significant herding at industry but not the firm level. To test this hypothesis, we looked at the 54 two-digit SIC industries with at least 10 stocks traded in our sample in each quarter. For each money manager, for each "industry-quarter," we computed the dollar purchases and dollar sales. A value of 1 was assigned to a money manager if he was a net buyer, and 0 if he was a net seller. For each industry-quarter, then, we had the number of buyers and the number of sellers, and could compute our herding measure treating the whole industry as if it were a single stock. This calculation produced a herding measure of .013 , suggesting even less herding at the industry level than at the individual stock level.

The issue of herding at the industry level leads us to discuss a central limitation of this paper, namely that we cannot say anything about stock-market-wide herding. It is possible that while there is very little herding in individual stocks and industries, 
there are times when money managers simultaneously all move into stocks and times when they all move out of stocks. Since our data set contains only all-equity funds, we cannot examine this type of herding.

A final issue we consider is the possibility of herding among subsets of money managers. One alternative is that money managers with a similar amount of money under management herd with each other, on the theory that similarly-sized money managers are in more direct competition for fund sponsors. Accordingly, we have divided our money managers into quintiles once a year by asset size under management, and computed our measure of herding within manager size quintiles. Panel $\mathrm{C}$ of Table 3 presents the results. There is less herding among the smallest managers than among the largest managers, but neither group herds a lot. Like the evidence on the subgroups of stocks and industries, this evidence on subgroups of money managers reveals little herding.

\section{Feedback Strategies}

At any level of herding, institutional investors have more potential to destabilize asset prices if they follow strong positive-feedback strategies. Our earlier analysis was based on a count of money managers, which is the right measure of herding, and not on the amount of excess demand. From the point-of-view of destabilization of prices, the relevant variable is excess demand. We, therefore, compute current quarter's net buying (aggregated across all money managers in a given stock) conditional on the past quarter's as well as on the past year's stock performance.

We use two measures of excess demand in a quarter, Dratio (dollar ratio) and Nratio (numbers ratio). For a given stock-quarter, i, Dratio is defined as:

(2) $\operatorname{Dratio}(i)=\frac{\text { \$buys }(i)-\$ \text { sells }(i)}{\text { \$buys }(i)+\$ \text { sells }(i)}$ 
where \$buys(i) is total dollar increases by all money managers in the given stockquarter (evaluated at the average price during the quarter), and \$sells(i) is similarly defined as total dollar decreases in holdings. Similarly, Nratio is defined as:

(3) $\operatorname{Nratio}(i)=\frac{\text { \#buys(i) }}{\text { \#active(i) }}$

where \#buys(i) is the number of money managers increasing the holding of the stock in quarter $i$, and \#active(i) is the number of money managers changing their holdings. In the results presented below, Dratios and Nratios are simple averages taken over all stock-quarters in a given group. We use two measures because they might, in principle, yield different results. For example, most managers might be engaged in positive-feedback trading, but the negative-feedback managers might be making the larger trades, in which case trend chasing would show up in the Nratio but not in the Dratio.

Table 4 presents the results for Dratio and Nratio by past-quarter performance quintiles and size quintiles. The results for Dratio show fairly substantial trend chasing for smaller stocks: the excess of sales over purchases in the worst performing smallest stocks is 18 percent of total value traded, whereas the excess of purchases over sales among best performing smallest stocks is 3.6 percent. A similar pattern is also observed in the second smallest size category. Moreover, in both of these size quintiles, excess demand is monotonically increasing in performance. As we move to larger stocks, the relationship between excess demand and past performance disappears. Among the largest quintile stocks, where increases in holdings always exceed decreases, there is no evidence whatsoever of positive-feedback trading. The results thus reveal positive-feedback trading for the smaller, but not for the larger, stocks. Aggregating across all size groups, we do not see any evidence of positive- 
feedback trading on average, because of the concentration of trades in larger stocks.

The results for Nratio, like those for Dratio, point to positive-feedback trading in small but not in large stocks. In small stocks, 42 percent of money managers changing their holdings of worst performers are buyers, whereas 51 percent of the money managers changing their holdings of best performers are buyers. Within this size quintile, Nratio increases monotonically with past performance. Positive-feedback trading is still evident in the second size quintile, but disappears in larger quintiles. Finally, Table 5 reports the results on trading as a function of past-year performance and size. Consistent with the results in Table 4, there is evidence of positive-feedback trading in small but not in large stocks.

The result of positive-feedback trading in smaller stocks is intriguing. Perhaps the most obvious explanation is window dressing: money managers dump losers among small stocks to dress up their portfolios. The strategy of dumping small stock losers makes sense if sponsors are less sensitive to holdings of poorly performing blue chips than to holdings of poorly performing unknown stocks.

The observed positive-feedback strategies in smaller stocks might also be a consequence of institutional practices and constraints that funds face. For example, past losers dumped by money managers might be fallen angels who stopped dividend payments. Some institutions might be prohibited from holding such stocks. Alternatively, money managers might restrict their holdings of small capitalization or illiquid stocks, which creates a positive correlation between past returns and institutional excess demand. It is not clear then, whether we are finding evidence of behavioral strategies, agency problems, or of simple institutional restrictions. Regardless of the motive for such positive-feedback trading, it might have an impact on share prices of small stocks. 
Incidentally, this result for small stocks is suggestive of the evidence that overreaction is concentrated in small stocks (Chopra, Lakonishok, and Ritter 1991). If institutional investors change their demand for these stocks in response to extreme performance, and if their demand affects prices in the short run, we would expect to observe overreaction.

The preferred habitat of institutional investors is in large stocks, however, and that is where their trading strategies are probably most important. For these stocks, we see no evidence of positive-feedback trading. Under the most common notion of destabilizing speculation, this implies that institutions are not destabilizing. The evidence on trend chasing in the largest stocks, like the evidence on herding, strongly points against the accusation that institutional investors destabilize prices of the individual stocks they trade. Of course, our analysis leaves open the possibility that institutional investors destabilize prices of individual stocks at a higher frequency, or that they destabilize aggregate stock prices.

\section{Institutional Excess Demand and Contemporaneous Price Movements}

We have looked at two possible ways in which trading by institutions might destabilize stock prices and found little evidence that either of these is very important. Our analysis begs the obvious question: why haven't we looked directly at the contemporaneous correlation between institutional excess demand and price changes? In this section, we analyze the relationship between demand for stocks by our money managers and contemporaneous stock returns.

This analysis, however, is not necessarily a superior way to address the question of destabilizing speculation, for two reasons. First, even if institutions affect prices, they might move them toward, rather than away from, fundamentals. Second, and more importantly, our data set is not ideal for analyzing the impact of institutional 
demand on prices. Our data contains quarterly changes in institutional holdings, and, therefore, we can compute quarterly changes in demand. But, looking at the quarterly data does not enable us to separate within-quarter trading strategies that respond to within-quarter price moves from the impact of trades on prices. For example, if we found that a particular group of stocks that institutions bought in a quarter rose in price in that quarter, it may be evidence of either responsiveness of positive-feedback trading to short-term price moves, or of the effect of institutional trading on prices, or even of both effects operating at the same time. In interpreting the results presented below, it is crucial to recognize this limitation of quarterly data.

Table 6 presents some basic statistics on the relationship between institutional demand for stocks in a quarter and size-adjusted excess returns in that quarter, which are computed by deducting from the quarterly buy and hold stock return the return on an equally-weighted quarterly buy and hold portfolio of its size decile. The cut-off points for size deciles were updated quarterly. In each quarter, we divided stocks traded by our money managers into two broad categories: stocks of which in aggregate they were net buyers; and those of which in aggregate they were net sellers. Each category is, in turn, divided into three groups depending on the size of the imbalance between dollar purchases and dollar sales (scaled by market capitalization). Small excess refers to the bottom quartile of stocks in terms of dollar excess demand, medium excess to the middle half, and large excess to the quartile of firms with largest excess demand in dollar terms. The same groups are defined for firms for which sales exceed purchases.

The results in Table 6 show a statistically and substantively significant sizeadjusted excess return of 1.8 percent per quarter for firms that were on net bought by our money managers. This result may reflect a price impact of institutional trades, 
which might, but does not have to be, destabilizing. The positive excess return could also result from positive-feedback trading in response to recent price increases, without causing these increases. When we look at the subcategories of net buying by the magnitude of our institutions' excess demand, waters get a little muddier. The abnormal return is actually somewhat smaller for large excess demand cases than for cases with small excess demand.

For stocks which are on net sold by institutions, the abnormal return is substantially lower than for stocks which are on net bought, although in magnitude the former return is a fairly small -.3 percent in the quarter. The average excess return, however, is a more substantial -1.7 percent for firms where the excess of sales over purchases is the largest. This might be evidence of destabilization or of responsiveness of demand to very recent price movements.

To clarify the above picture, the analysis was extended to five size quintiles, and size-adjusted abnormal returns are calculated for each of the size groups. The results are also presented in Table 6. As before, results differ substantially by size group. For the smallest stocks, the average abnormal return when purchases exceed sales is close to zero. Within that category more buying is not associated with higher returns: in fact, the mean abnormal return on smallest stocks with the largest excess demand is -2.9 percent. On the other hand, the returns on the smallest stocks for which sales exceed purchases are sharply negative. Moreover, they are the most negative when the excess supply by institutions is the largest. This evidence suggests that, within smallest stocks, either institutions sell recent losers, or they depress the prices of stocks they sell.

The results for the second size quintile are consistent with either intraquarter positive-feedback trading or the direct impact of institutional trades on share prices. 
The mean abnormal return for stocks for which purchases exceed sales is 2.8 percent, and the mean return for stocks for which sales exceed purchases is -1.8 percent. These returns are roughly monotonic in the magnitude of excess demand. In the third size quintile, we again see positive returns for stocks for which purchases exceed sales, but negative returns only for stocks for which the excess of sales over purchases is the largest. There is, however, again a rough monotonic relationship between excess demand and abnormal returns, indicating either price pressure by institutions or intraquarter positive-feedback trading.

Even these rough relationships, however, disappear in the two largest size quintiles, where institutional trading is concentrated. In the fourth quintile, both the stocks which are on net bought and the stocks which are on net sold earn a positive excess return. Moreover, stocks for which the excess supply by institutions is the largest have an abnormal return of 2.0 percent. In the largest quintile, stocks which institutions on net buy have lower abnormal returns than stocks which institutions on net sell, which seems more consistent with stabilizing negative-feedback trading. Indeed, stocks with the largest excess demand have a return of -.5 percent, and stocks with the largest excess supply have a return of 3.1 percent. What little support we saw for positive-feedback trading or price pressure from institutions in smaller quintiles disappears in the largest two quintiles.

In sum, the results of this section are the least conclusive. Stocks that institutions buy on net have higher contemporaneous abnormal returns than stocks that institutions sell on net. However, a closer inspection reveals that this result is driven by the smaller stocks, particularly those in the second and third quintiles. In the largest two quintiles, the pattern of abnormal returns for the net buy and net sell cases is essentially identical. For the smallest quintile stocks, when institutions are net 
sellers, a monotonic relationship between gradations of excess supply and abnormal returns is observed. However, no such relationship exists for stocks which institutions buy on net. In light of this evidence, the destabilizing effect of institutions in individual stocks, even if it exists, is unlikely to be large.

\section{Conclusion}

This paper has presented evidence on the herding and trend-chasing behavior of institutional money managers. We found weak evidence of herding, and somewhat stronger evidence of positive-feedback trading, in smaller stocks. However, there is virtually no evidence of either herding or positive-feedback trading in the largest stocks, where most institutional holdings and trading are. There is also no consistent evidence of a significant positive correlation between changes in institutional holdings and contemporaneous excess returns, except again in small stocks where we may just be observing intraquarter positive-feedback trading. We conclude that there is no solid evidence in our data that institutional investors destabilize prices of individual stocks. Instead, the emerging image is that institutions follow a broad range of styles and strategies and their trades offset each other without having a large impact on prices. We must conclude, however, with two caveats: our results do not preclude market-wide herding, such as would occur if money managers followed each other in market timing strategies, or herding in individual stocks at higher-than-quarterly frequencies. 


\section{Bibliography}

Andreassen, Paul and A. Kraus (1988). "Judgmental Prediction by Extrapolation," Working Paper, Harvard University.

Banerjee, Abhijit. "A Model of Herd Behavior," Quarterly Journal of Economics (1991), forthcoming.

Chopra, Navin, Josef Lakonishok, and Jay Ritter. "Performance Measurement Methodology and the Question of Whether Stocks Overreact" (1991), unpublished paper.

Cutler, David, James M. Poterba, and Lawrence H. Summers. "Speculative Dynamics and the Role of Feedback Traders," American Economic Review Papers and Proceedings (1990),63-68.

DeBondt, Werner and Richard Thaler. "Does the Stock Market Overreact?" Joumal of Finance (1985), 793-809.

De Long, J. Bradford, Andrei Shleifer, Lawrence H. Summers, and Robert J. Waldmann. "Positive Feedback Investment Strategies and Destabilizing Rational Speculation." Journal of Finance (1990), 379-395.

Friend, Irwin, Marshall Blume and Jean Crockett. Mutual Funds and Other Institutional Investors (1970), McGraw-Hill Book Company.

Kraus, Alan and Hans R. Stoll. "Parallel Trading by Institutional Investors," Journal of Financial and Quantitative Analysis (1972), 2107-2138.

Lakonishok, Joseph, Andrei Shleifer, Richard Thaler, and Robert W. Vishny.

"Window Dressing by Pension Fund Managers." American Economic Review Papers \& Proceedings (1991), 227-231.

Scharfstein, David S. and Jeremy C. Stein. "Herd Behavior and Investment." American Economic Review (1990), 465-479.

Schwartz, Robert and James Shapiro. "The Challenge of Institutionalization for the Equity Market," Working Paper, New York University.

Shiller, Robert J. and John Pound. "Survey Evidence on Diffusion of Interest and Information among Investors," Journal of Economic Behavior and Organization (1989), 47-66. 


\section{TABLE 1}

\section{Sample Characteristics}

Number of changes in holdings and dollar value of changes (in millions) by size (market capitalization) quintiles determined from the universe of NYSE and AMEX stocks. The numbers in parenthesis are the percentage of changes in holdings and the percentage of dollar value of changes in holdings by size quintiles.

\begin{tabular}{|c|c|c|}
\hline Quintile & $\begin{array}{c}\text { Number of } \\
\text { Changes in Holdings }\end{array}$ & $\begin{array}{c}\text { Dollar Value of } \\
\text { Changes in Holdings } \\
\text { (in millions) }\end{array}$ \\
\hline Smallest & $\begin{array}{c}338 \\
(1.3 \%)\end{array}$ & $\begin{array}{c}270 \\
(.07 \%)\end{array}$ \\
\hline 2 & 2,087 & 1,648 \\
$(7.9 \%)$ & $11,030)$ \\
\hline 3 & 5,515 & $(2.8 \%)$ \\
\hline 4 & $(21 \%)$ & 50,373 \\
& 8,963 & $(12.7 \%)$ \\
\hline Largest & $(34 \%)$ & 333,310 \\
& 9,389 & $(84 \%)$ \\
\hline
\end{tabular}




\section{TABLE 2}

\section{Herding Statistics for All Stock-Quarters and for Stock-Quarters with Active Trading}

The mean and median herding statistics are presented for all cases ("stock-quarter") and for cases where more than 10 and more than 20 money managers were active.

\begin{tabular}{|l|c|c|c|}
\hline & All Cases & $\begin{array}{c}\text { More than 10 Money } \\
\text { Managers Active }\end{array}$ & $\begin{array}{c}\text { More than } 20 \text { Money } \\
\text { Managers Active }\end{array}$ \\
\hline Mean & .027 & .020 & .021 \\
\hline Median & .001 & .001 & .002 \\
\hline
\end{tabular}




\section{TABLE 3}

\section{Herding Statistics by Firm Size, Past-Quarter Performance, and by Money under Management}

Panel $A$ reports the mean herding statistic by firm size (market capitalization) quintiles. Panel B reports the mean herding statistic by past-quarter return quintiles. Panel $\mathrm{C}$ reports the mean herding statistic by money under management quintiles determined from the universe being evaluated by SEI.

Panel A: By Firm Size

\begin{tabular}{|c|c|c|c|c|c|}
\hline & $\begin{array}{c}\text { Quintile 1 } \\
\text { (Small) }\end{array}$ & Quintile 2 & Quintile 3 & Quintile 4 & $\begin{array}{c}\text { Quintile 5 } \\
\text { (Large) }\end{array}$ \\
\hline Mean & .061 & .039 & .028 & .020 & .016 \\
\hline
\end{tabular}

Panel B: By Past-Quarter Performance

\begin{tabular}{|r|c|c|c|c|c|}
\hline & $\begin{array}{c}\text { Quintile 1 } \\
\text { Worst }\end{array}$ & Quintile 2 & Quintile 3 & Quintile 4 & $\begin{array}{c}\text { Quintile 5 } \\
\text { (Best) }\end{array}$ \\
\hline Mean & .020 & .018 & .020 & .024 & .027 \\
\hline
\end{tabular}

Panel C: By Assets under Management

\begin{tabular}{||c|c|c|c|c|c|}
\hline & $\begin{array}{c}\text { Quintile 1 } \\
\text { (Smallest) }\end{array}$ & Quintile 2 & Quintile 3 & Quintile 4 & $\begin{array}{c}\text { Quintile 5 } \\
\text { (Largest) }\end{array}$ \\
\hline Mean & .006 & .016 & .016 & .012 & .018 \\
\hline
\end{tabular}


TABLE 4

\section{Past-Quarter Performance and Trading Activity of Money Managers by Size Quintiles}

In Panel $\mathrm{A}$, the mean excess demand by past-quarter performance and size (market capitalization) is presented. The excess demand for a given "stock-quarter," Dratio, is defined as the difference between dollar buys and dollar sells scaled by total activity ( $\$$ buys $+\$$ sells). In Panel $\mathrm{B}$, the proportion of money managers that are net buyers, Nratio, by past-quarter performance and size is presented.

\begin{tabular}{||l|c|c|c|c|c||}
\hline & \multicolumn{5}{|c|}{ Size } \\
\hline $\begin{array}{l}\text { Past-Quarter } \\
\text { Performance }\end{array}$ & Small & 2 & 3 & 4 & Large \\
\hline \multicolumn{7}{|l||}{ Panel A: Excess Demand (Dratio) } \\
\hline Worst & -.180 & -.030 & .105 & .047 & .016 \\
\hline 2 & -.159 & -.080 & -.047 & -.107 & .058 \\
\hline 3 & -.057 & -.015 & .017 & .025 & .110 \\
\hline 4 & -.005 & .038 & .077 & .063 & .025 \\
\hline Best & .036 & .056 & .052 & .055 & .011 \\
\hline Panel B: Proportion of Money Managers Buying (Nratio) & \\
\hline Worst & .42 & .48 & .55 & .53 & .49 \\
\hline 2 & .42 & .47 & .46 & .44 & .53 \\
\hline 3 & .48 & .50 & .51 & .51 & .54 \\
\hline 4 & .49 & .52 & .54 & .53 & .51 \\
\hline Best & .51 & .52 & .52 & .52 & .49 \\
\hline
\end{tabular}


TABLE 5

Past-Year Performance and Trading Activity of Money Managers by Size Quintiles

In Panel $A$, the mean excess demand by past-year performance and size (market capitalization) is presented. The excess demand for a given "stock-quarter," Dratio, is defined as the difference between dollar buys and dollar sells scaled by total activity ( $\$$ buys $+\$$ sells). In Panel $B$, the proportion of money managers that are net buyers, Nratio, by past-year performance and size is presented.

\begin{tabular}{||l|c|c|c|c|c||}
\hline & \multicolumn{5}{|c|}{ Size } \\
\hline $\begin{array}{c}\text { Past-Year } \\
\text { Performance }\end{array}$ & Small & 2 & 3 & 4 & Large \\
\hline \multicolumn{5}{|l||}{} \\
Panel A: Excess Demand (Dratio) \\
\hline Worst & -.158 & -.222 &. .101 & .005 & .025 \\
\hline 2 & -.035 & -.077 & .012 & .045 & .042 \\
\hline 3 & -.056 & .029 & .041 & .042 & .067 \\
\hline 4 & .068 & .073 & .029 & .032 & .051 \\
\hline Best & .059 & -.001 & .090 & .036 & .012 \\
\hline Panel B: Proportion of Money Managers Buying (Nratio) & \\
\hline Worst & .42 & .39 & .46 & .50 & .52 \\
\hline 2 & .48 & .46 & .51 & .52 & .51 \\
\hline 3 & .47 & .47 & .51 & .52 & .51 \\
\hline 4 & .54 & .53 & .51 & .52 & .51 \\
\hline Best & .53 & .49 & .54 & .52 & .50 \\
\hline
\end{tabular}


TABLE 6

\section{Contemporary Excess Demand and Quarterly Returns}

Average abnormal quarterly returns (size-adjusted) are presented for various levels of excess demand. The results are presented for all firms as well as by firm size. Excess demand is defined as dollar buys minus dollar sales scaled by market capitalization. Small excess refers to the bottom quartile of stocks in terms of dollar excess demand (supply), medium excess to the middle half, and large excess to the quartile of stocks with the largest excess demand. The numbers in parenthesis are t-statistics.

\begin{tabular}{|c|r|r|r|r|r|r||}
\hline Category & $\begin{array}{c}\text { All } \\
\text { Firms }\end{array}$ & Small & \multicolumn{1}{c|}{2} & \multicolumn{1}{c|}{3} & \multicolumn{1}{c|}{4} & Large \\
\hline \$ Buys Exceeds \$ Sells & .018 & -.007 & .028 & .027 & .017 & .010 \\
& $(13.70)$ & $(-.97)$ & $(6.46)$ & $(10.00)$ & $(8.13)$ & $(6.04)$ \\
\hline Small Excess & .016 & -.014 & .017 & .027 & .015 & .016 \\
& $(6.47)$ & $(-1.03)$ & $(2.39)$ & $(5.00)$ & $(3.54)$ & $(4.37)$ \\
\hline Medium Excess & .021 & .006 & .042 & .029 & .017 & .013 \\
& $(11.80)$ & $(5.24)$ & $(6.25)$ & $(7.47)$ & $(5.83)$ & $(6.31)$ \\
\hline Large Excess & .013 & -.029 & .016 & .025 & .021 & -.005 \\
& $(4.58)$ & $(-1.78)$ & $(1.87)$ & $(4.68)$ & $(4.48)$ & $(-1.13)$ \\
\hline \$ Sells Exceeds \$ Buys & -.003 & -.083 & -.018 & .003 & .013 & .016 \\
& $(-2.02)$ & $(-12.8)$ & $(-4.86)$ & $(8.52)$ & $(5.00)$ & $(7.87)$ \\
\hline Small Excess & .004 & -.072 & -.002 & .014 & .013 & .013 \\
& $(1.59)$ & $(-5.32)$ & $(-2.70)$ & $(2.67)$ & $(2.97)$ & $(3.27)$ \\
\hline Medium Excess & .001 & -.069 & -.007 & .010 & .009 & .013 \\
& $(.31)$ & $(-7.50)$ & $(-1.23)$ & $(2.35)$ & $(2.65)$ & $(5.13)$ \\
\hline Large Excess & -.017 & -.115 & -.057 & -.019 & .020 & .031 \\
& $(-5.08)$ & $(-9.27)$ & $(-7.79)$ & $(-3.07)$ & $(3.21)$ & $(5.04)$ \\
\hline
\end{tabular}

